\title{
Evaluation of the Toxicity Profile of Bridelia ferruginea Methanol Stem Bark Extract
}

\author{
${ }^{*}$ Galalain, A. M. ${ }^{1}$, Aliyu, B. S. ${ }^{1}$ \\ Department of Plant Biology, \\ Faculty of Life Sciences, \\ Bayero University, \\ Kano, Nigeria
}

Email: amgalalain.bot@buk.edu.ng

\begin{abstract}
The present research was carried out to investigate the toxicity profile of Bridelia ferruginea methanol stem bark extract. Acute toxicity study was carried out in mice using the modified Lorke's method to determine median lethal dose $\left(L D_{50}\right)$. For the subacute toxicity study, animals used were albino rats while extract was administered at dose levels of 100, 1000 and $2500 \mathrm{mg} / \mathrm{kg}$ daily for a period of 28 days. Blood samples were taken at the end of the study period for estimation of biochemical and haematological parameters. Histopathological examination of sections of the liver and kidney was also carried out. No mortality was recorded in acute toxicity study and also no any change in general behaviour of rats was observed up to dose of $5000 \mathrm{mg} / \mathrm{kg}$. Similarly, daily administration of the stem bark extract for 28 days did not produce significant changes in body weight, haematological and biochemical parameters of treated rats across all doses except at dose of $2500 \mathrm{mg} / \mathrm{kg}$ where significant change was observed in the parameters studied when compared with values obtained from the control group. However, slight histopathological changes were observed in the liver and kidneys sections of rats treated with the methanol stem bark at dose of $1000 \mathrm{mg} / \mathrm{kg}$ and $2500 \mathrm{mg} / \mathrm{kg}$. In conclusion, based on results of acute and subacute toxicity study studies, the methanol stem bark extract of Bridelia ferruginea may be considered safe for medicinal use especially at lower doses.
\end{abstract}

Keywords: Bridelia ferruginea, Acute Toxicity, Subacute Toxicity, Methanol Extract, Euphorbiaceae

\section{INTRODUCTION}

According to Adesina et al. (2010) a number of plants and plant-based products have been used to treat various diseases in almost all cultures. The increase in number of herbal drug users in the world makes it necessary to investigate the toxicity profile of herbal products (Saad et al., 2006). Thus, toxicity studies on experimental animals will provide essential data in establishing the safety of medicinal plants for human use (Moshi, 2007).

Bridelia ferruginea which belong to the family Euphorbiaceae is a plant species that has been widely reported to have variety of pharmacological effects; including antidiabetic properties (Njamen et al., 2012). According to Akuodor et al. (2011), extract of B. ferruginea stem bark has been reported to have potent analgesic and anti-diarrheal properties when tested on rats and 
mice. Ethnobotanical literature also reported the folklore use of aqueous extract of $B$. ferruginea stem bark as anti-diarrheal agent and for ulcer-protective (Akuodor et al. 2012).

The stem bark of Bridelia ferruginea is widely used in traditional medicine for treating various diseases. This makes it a potential candidate for drug development. Hence, it is essential to confirm the safety of the plant extract. This will assist in the selection of safe doses during the process of drug development. Hence, the aim of the present work was to evaluate the safety profile of Bridelia ferruginea methanol stem bark extract through acute and sub-acute toxicity studies.

\section{MATERIALS AND METHODS}

\section{Preparation of Plant Extract}

Fresh stem bark of Bridelia ferruginea was collected and taken to the Herbarium unit of the Plant Biology Department, Bayero University, Kano for authentication. The fresh stem bark was dried under shade and pulverized into a fine powder. Two hundred grams ( $200 \mathrm{~g})$ of the dried powder was extracted with $1000 \mathrm{ml}$ of $70 \%$ methanol for $72 \mathrm{hr}$ using maceration method, and the filtrate was evaporated to dryness on a water bath to obtain the crude extract.

\section{Acute Toxicity Study}

The study was conducted to determine median lethal dose (LD50) of the methanol extract of Bridelia ferruginea stem bark in albino mice. The modified Lorke method as described by Bariweni et al. (2018) was adopted. The experiment was carried out in two phases. In the $1^{\text {st }}$ Phase, twelve mice were randomly divided into four groups each containing three mice. Animals in group 1 received $10 \mathrm{ml} / \mathrm{kg}$ distilled water while in group 2, 3 and 4 the animals received 10, 100 and $1000 \mathrm{mg} / \mathrm{kg}$ of the extract respectively via the intraperitoneal route. Animals were observed for 24 hours for any change in general behaviour or mortality.

In $2^{\text {nd }}$ Phase, eight mice were randomly divided into 4 groups containing two mice each. Animals in group 1 also received $10 \mathrm{ml} / \mathrm{kg}$ distilled water while in group 2, 3 and 4 the animals received 1600, 2900 and $5000 \mathrm{mg} / \mathrm{kg}$ of methanol extract respectively. The animals were observed as in $1^{\text {st }}$ Phase. The $\mathrm{LD}_{50}$ was calculated using the formula; $\mathrm{LD}_{50}=\sqrt{ } a \times b$

Where $\boldsymbol{a}$ is the highest dose at which no death occurred in the $2^{\text {nd }}$ phase and $\boldsymbol{b}$ is the least dose at which death occurred in the $2^{\text {nd }}$ phase.

\section{Sub-acute Toxicity Study}

The study was carried out according to method described by Larbie et al. (2015). Twenty adult albino rats were selected and divided into four groups each containing five rats. Three different doses were administered $(100,1000$ and $2500 \mathrm{mg} / \mathrm{kg})$ to respective groups of rats while animals in the control group received $10 \mathrm{ml} / \mathrm{kg}$ distilled water daily for 28 days. Weight of the animals was taken on the first and last day of experiment. The rats were sacrificed at the end of the experiment and blood samples were collected for estimation of haematological and biochemical parameters.

\section{Biochemical and Haematological Analyses}

Biochemical parameters which include; Alanine Transaminase (ALT), Aspartate Transaminase (AST), Alkaline phosphatase (ALP), Albumin, Total protein, Urea, Creatinine and serum electrolytes (Sodium, Potassium, Chloride and Bicarbonate) were evaluated following standard procedures as described in the respective assay kits. While Red and White blood cells, Haemoglobin and the packed cell volume were analysed using automated haematology analyser. 


\section{Histopathological examinations of organs}

Liver and kidney Sections were obtained at the thickness of 5-6 $\mu \mathrm{m}$ and stained with routine hematoxylin and eosin. Stained sections were examined under the microscope and photomicrographs of the sections were taken at $\times 250$ magnification.

\section{Statistical Analysis}

Results obtained were expressed as mean \pm standard error of mean. Data analysis was performed using one-way analysis of variance and Dunnet post-hoc test (for comparison between control and treatment groups). The difference between means was considered significant at $\mathrm{p}<0.05$.

\section{RESULTS}

In acute toxicity study, no mortality was recorded in all groups of animals following the administration of Bridelia ferruginea methanol stem bark up to dose of $5000 \mathrm{mg} / \mathrm{kg}$. (Table 1), and none of the animals showed any signs of toxicity or behavioural changes during the study period.

Table 1: Acute toxicity studies of Bridelia ferruginea methanol stem bark extract

Phase I

\begin{tabular}{lccc}
\hline Group & No. of rats & Doses $\mathbf{( m g / k g )}$ & Mortality recorded after 24hrs \\
\hline I & 3 & 10 & $0 / 3$ \\
II & 3 & 100 & $0 / 3$ \\
III & 3 & 1000 & $0 / 3$
\end{tabular}

\begin{tabular}{lccc}
\hline Phase II & & & \\
\hline Group & No. of rats & Doses $\mathbf{( m g} / \mathbf{k g})$ & Mortality recorded after 24hrs \\
\hline I & 2 & 1600 & $0 / 2$ \\
II & 2 & 2900 & $0 / 2$ \\
III & 2 & 5000 & $0 / 2$
\end{tabular}

Result of the effect of Bridelia ferruginea methanol extract on body weight of rats is presented in Figure 1. An increase in body weight was recorded after repeated administration of the extract for 28 days in all treated rats except the animals that received $2500 \mathrm{mg} / \mathrm{kg}$ of extract, where a slight reduction in body weight was recorded at the end of the experiment compared to their initial body weight on day 0 (Figure 1).

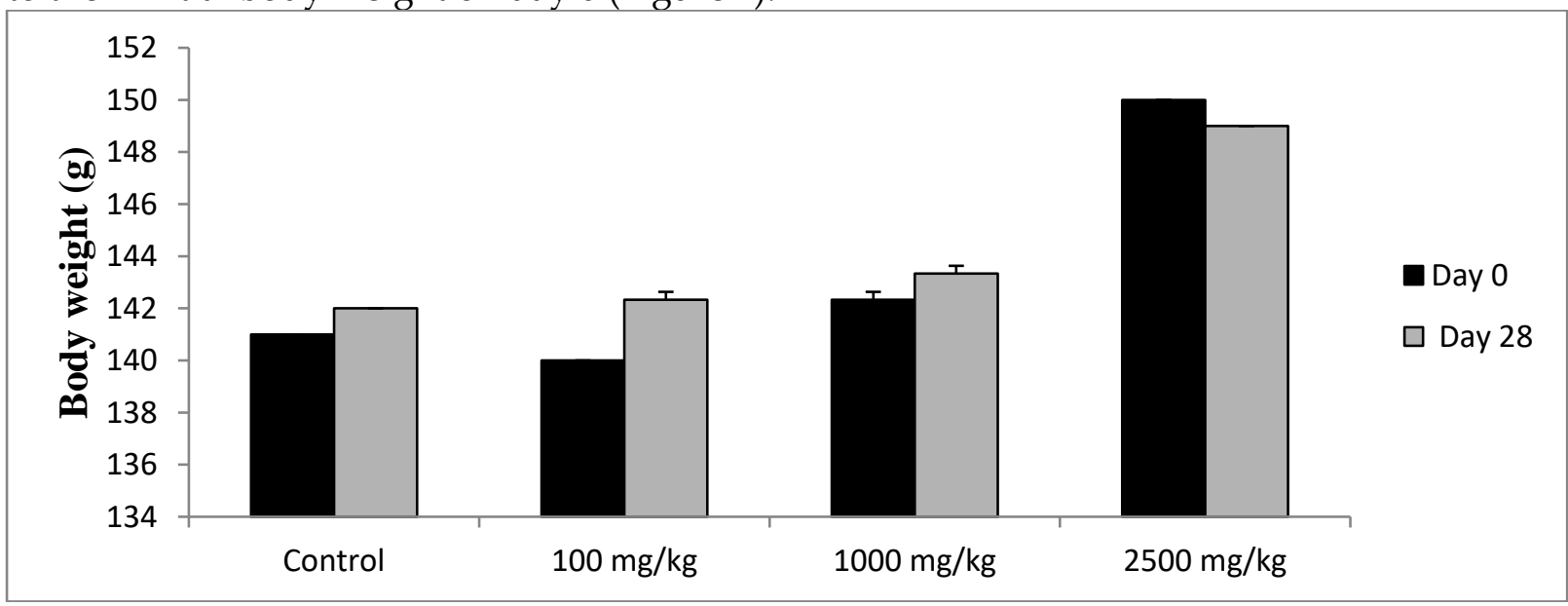


Figure 1: Changes in Body weight of rats following administration of extract for 28 days

Effect of the methanol stem bark extract of Bridelia ferruginea on liver and kidney function parameters of rats are summarized in Figures 2 and 3 below. From the results obtained, levels of the liver function parameters in treated rats at dose of $100 \mathrm{mg} / \mathrm{kg}$ and $1000 \mathrm{mg} / \mathrm{kg}$ were found to be similar to those in the control group, while significant change was observed only in the group of rats treated with $2500 \mathrm{mg} / \mathrm{kg}$. The same pattern was observed with the kidney function parameters; also no significant difference $(p>0.05)$ was observed in levels of serum urea and creatinine at $100 \mathrm{mg} / \mathrm{kg}$ and $1000 \mathrm{mg} / \mathrm{kg}$ dose of extract in comparison with control group. While at $2500 \mathrm{mg} / \mathrm{kg}$ there was elevation in the levels of serum urea and creatinine in treated rats, but the values were within the normal range. Similarly, results obtained revealed that the stem bark extract did not produce significant changes in levels of Sodium, Potassium, Chloride and Bicarbonate ions across all doses (100, 1000 and $2500 \mathrm{mg} / \mathrm{kg}$ ) when compared with values obtained from the control group.

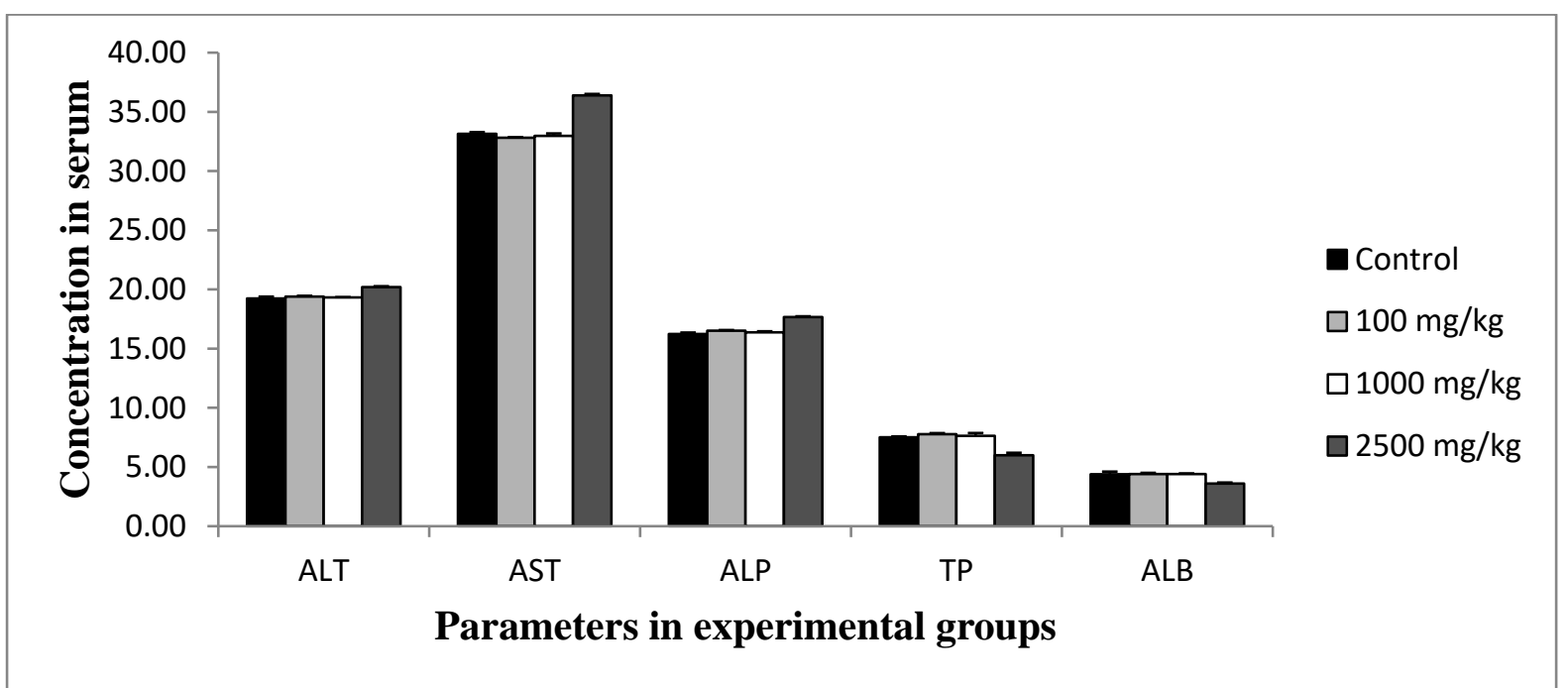

Figure 2: The Effect of Bridelia ferruginea methanol stem bark extract on liver function parameters of rats at the end of the study period

Key: ALT-Alanine Transaminase, AST-Aspartate Transaminase, ALP-Alkaline Phosphatase, ALB-Albumin, TPTotal protein. Each bar represents Mean \pm SEM of 5 rats per group

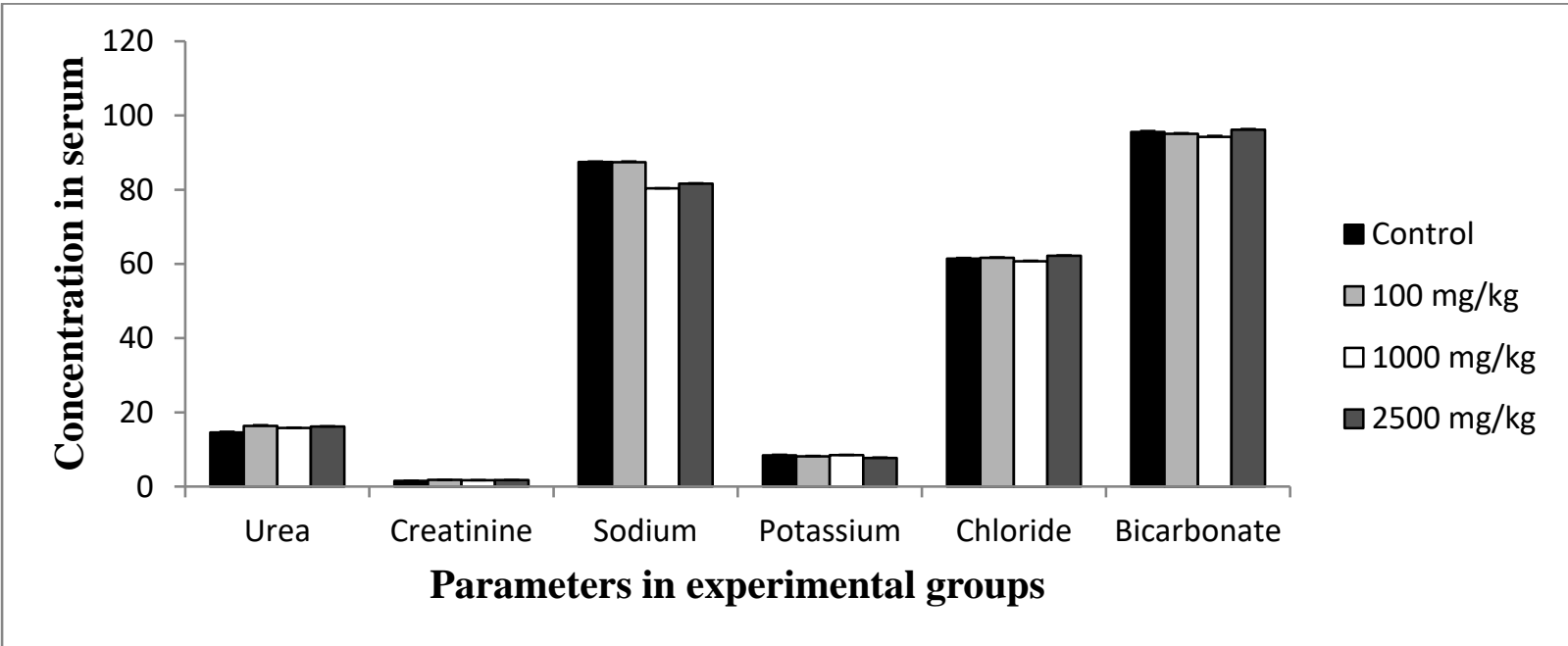

Figure 3: The Effect of repeated administration of Bridelia ferruginea methanol stem bark extract on kidney function parameters of rats 
Furthermore, the effect of different concentrations of Bridelia ferruginea methanol extract on some haematological parameters of treated rats also revealed that doses of the plant extract $(100 \mathrm{mg} / \mathrm{kg}$ and $1000 \mathrm{mg} / \mathrm{kg})$ did not alter levels of haematological parameters in treated rats when compared with values from the control group, while at $2500 \mathrm{mg} / \mathrm{kg}$ a slight decrease was observed in levels of the haematological parameters studied (Figure 4).

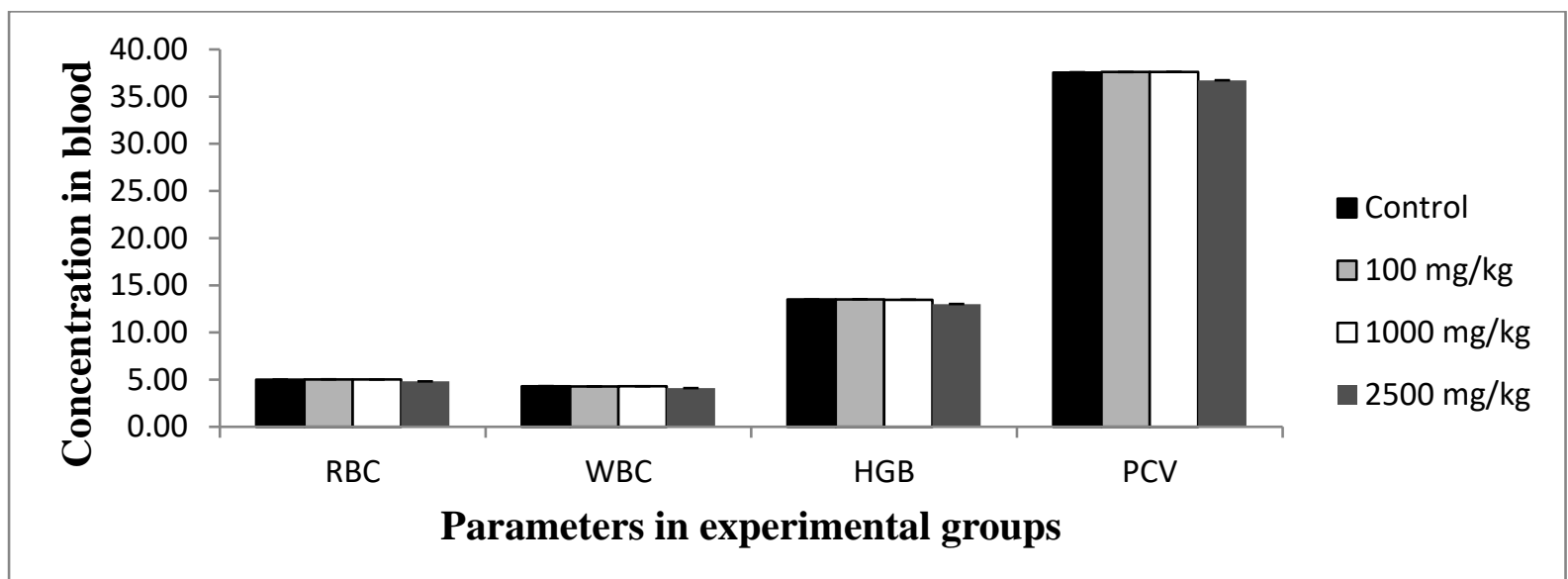

Figure 4: The Effect of Bridelia ferruginea methanol stem bark extract on some haematological parameters of the experimental rats

Key: RBC-Red blood cells, WBC-White blood cells, HGB-Haemoglobin, PCV-Packed cell volume. Each bar represents Mean \pm SEM of 5 rats per group

Microscopic examination of sections of the liver and kidney from rats treated with 1000 $\mathrm{mg} / \mathrm{kg}$ showed slight hepatic and tubular necrosis in the organs respectively (Figure 5(a) and (b)). Similarly, the kidney sections of rats that received $2500 \mathrm{mg} / \mathrm{kg}$ revealed moderate tubular adhesion (Figure 6(a)), while slight vascular congestion and lymphocyte hyperplasia with sinusoidal congestion were observed in liver sections of rats at $2500 \mathrm{mg} / \mathrm{kg}$ (Figure 6 (b)).

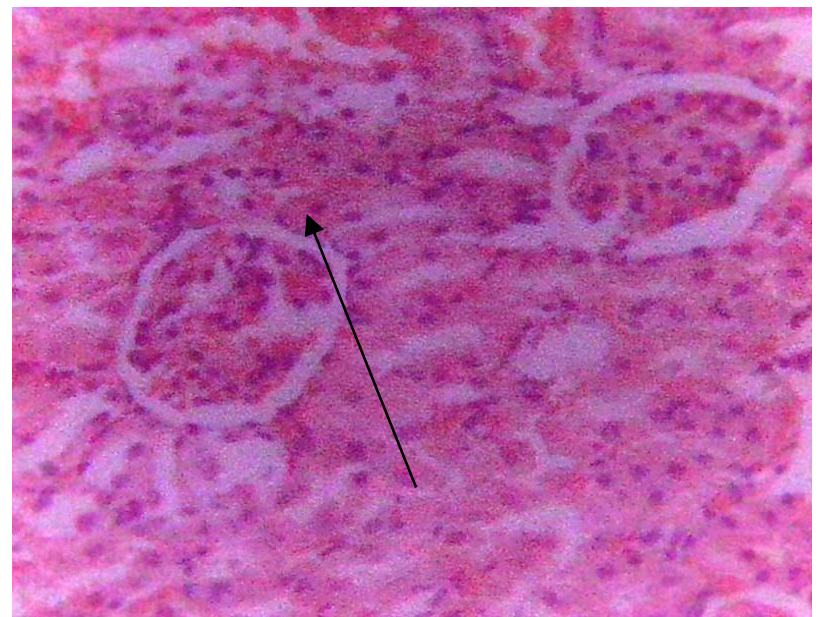

Figure 5: (a) Photomicrograph of kidney section from rats treated with $1000 \mathrm{mg} / \mathrm{kg}$ showing slight tubular necrosis

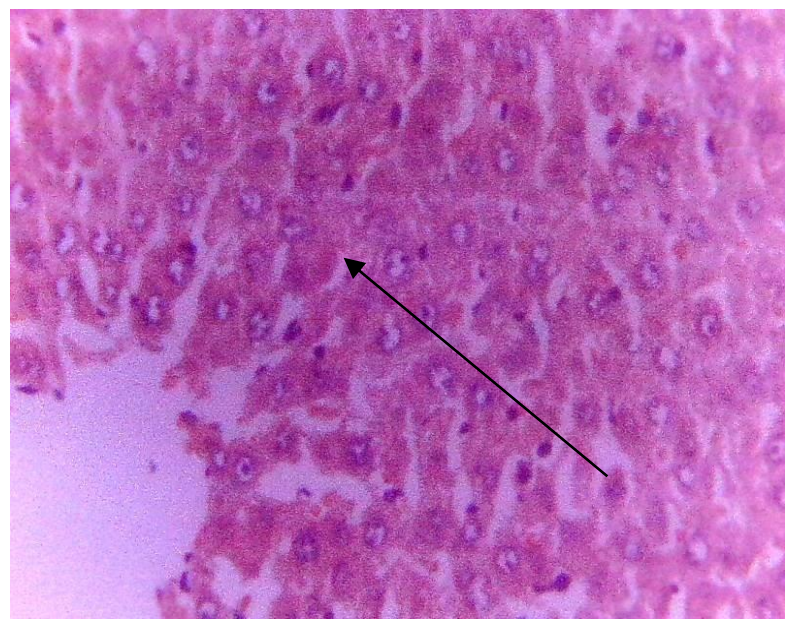

(b) Photomicrograph of the Liver section from rats treated with $1000 \mathrm{mg} / \mathrm{kg}$ showing slight hepatic necrosis 


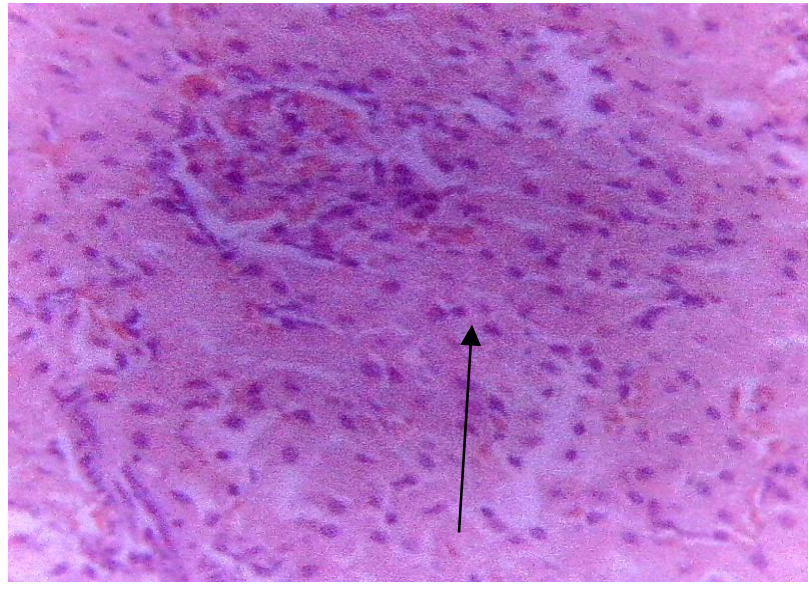

Figure 6: (a) Photomicrograph of kidney section from rats treated with $2500 \mathrm{mg} / \mathrm{kg}$ showing moderate tubular adhesion LH with SC

VC= Vascular congestion,

LH= Lymphatic hyperlasia

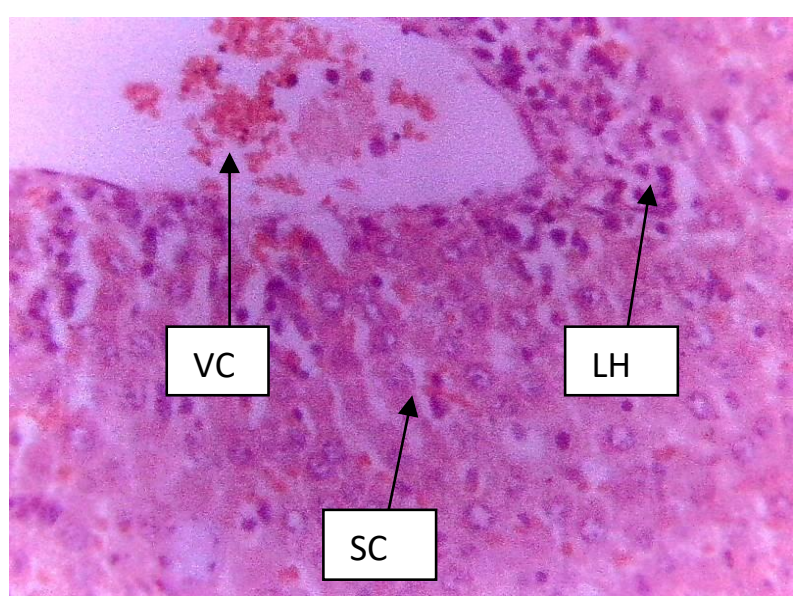

(b) Photomicrograph of the Liver section from rats treated with $2500 \mathrm{mg} / \mathrm{kg}$ showing slight $\mathrm{VC}$ and

$\mathrm{SC}=$ Sinusoidal congestion

\section{DISCUSSION}

Several studies reported that in screening drugs, determination of median lethal dose $\left(\mathrm{LD}_{50}\right)$ is usually the initial step in assessing toxicity profile of a test substance (Osibemhe et al., 2016). The present study was carried out to evaluate the safety profile of Bridelia ferruginea methanol stem bark extract through acute and subacute toxicity studies. Results from acute toxicity study revealed that the stem bark extract did not produce mortality or any behavioural changes in all the groups of mice up to dose of $5000 \mathrm{mg} / \mathrm{kg}$, which indicate that the $\mathrm{LD}_{50}$ value of the stem bark extract is greater than $5000 \mathrm{mg} / \mathrm{kg}$. Bariweni et al (2018) reported that according to Kennedy et al. (1986) any test substance with $\mathrm{LD}_{50}$ greater than $5000 \mathrm{mg} / \mathrm{kg}$ can be considered non toxic. The result agrees with findings of Awodele et al. (2015), who reported that aqueous stem bark extract of Bridelia ferruginea did not produce mortality in mice up to dose of $4000 \mathrm{mg} / \mathrm{kg}$.

In the sub-acute toxicity study, there was an increase in body weight of rats in the control group and extract-treated groups at $100 \mathrm{mg} / \mathrm{kg}$ and $1000 \mathrm{mg} / \mathrm{kg}$ after repeated administration of the extract for 28 days, while a slight decrease in body weight of the rats treated with 2500 $\mathrm{mg} / \mathrm{kg}$ was recorded. Previous studies suggested that reduction in body weight of experimental animals may probably be related to a reduction in daily food intake which may be due to stress (Ellacott et al., 2010).

In the case of biochemical parameters, no significant changes were observed in liver function indices and kidney function parameters of treated groups except at $2500 \mathrm{mg} / \mathrm{kg}$. According to Hilaly et al. (2004) AST, ALT and ALP are the common parameters used in the assessment of liver function. They are marker enzymes of liver; hence elevation in the concentration of marker enzymes is an indication of liver injury. According to Arsad et al. (2013), in the case of acute or chronic renal toxicity, the concentration of urea and creatinine are usually increased to four or five times higher than normal values in control animals. However, values obtained in the present study were still within the normal range, indicating that administration of Bridelia ferruginea stem bark extract did not induce toxicity on liver and kidney functions.

Arsad et al. (2013) reported that blood parameters are relevant indicators for risk evaluation. The mean values of haematological parameters recorded in the present study were similar to those of the control animals. This finding also agrees with the earlier work by Awodele et al. 
(2015), who reported that administration of aqueous extract of Bridelia ferruginea stem bark showed a non-significant increase in red blood cell, haemoglobin, platelet and the packed cell volume of the treated rats except at $4000 \mathrm{mg} / \mathrm{kg}$, where there was a slight decrease when compared with control group. According to Awodele et al. (2015), absence of significant changes on RBC, HGB, and PCV of treated rats might be an indication that administration of the extract did not lead to destruction of matured red blood cells.

Histopathological sections of kidney from rats treated with $1000 \mathrm{mg} / \mathrm{kg}$ and $2500 \mathrm{mg} / \mathrm{kg}$ revealed slight tubular necrosis and moderate tubular adhesion respectively. This is in line with findings of Kolawole et al. (2009) who reported acute pyelonephritis with edematous infiltration of cells in kidney of rats treated with Bridelia ferruginea stem bark extract. Similarly, Awodele et al. (2015) reported heavy lymphocytic infiltrates and sinusoidal congestion in the liver of rats treated with Bridelia ferruginea extract, which is in agreement with the results obtained in the present study following examination of liver sections from animals treated with $1000 \mathrm{mg} / \mathrm{kg}$ and $2500 \mathrm{mg} / \mathrm{kg}$ of extract. Kharchoufa et al. (2020) also reported a slight variation in kidney architecture of rats treated with Hibiscus sabdariffa extract; even though the extract did not produce significant changes in the biochemical markers of kidney function in all extract-treated groups. According to Kharchoufa et al. (2020) this is an indication that the extract did not produce nephrotoxicity sufficient to have an alteration of kidney functions.

\section{CONCLUSION}

Results obtained from acute toxicity study indicates that the methanol stem bark extract of Bridelia ferruginea may be considered safe up to dose level of $5000 \mathrm{mg} / \mathrm{kg}$. In subacute toxicity study, only the highest dose $(2500 \mathrm{mg} / \mathrm{kg})$ produced significant change in body weight, biochemical and haematological parameters of the rats. However, histopathological examination of the kidney and liver sections revealed that the extract at $1000 \mathrm{mg} / \mathrm{kg}$ and 2500 $\mathrm{mg} / \mathrm{kg}$ dose level induced mild toxicity in the two vital organs. Based on these findings, it is recommended that chronic toxicity studies should be conducted to assess the safety profile of the extract after long term administration.

\section{ACKNOWLEDGEMENT}

The Corresponding Author is thankful to the West African Research Association (WARA) and the Mastercard Foundation for providing financial support to conduct this research. Also special thanks to my Supervisor Prof. Bala Sidi Aliyu for guidance, assistance and valuable contributions. I am also very thankful to Prof. Musa Aliyu of the Faculty of Pharmaceutical Sciences, Bayero University, Kano, for innovative suggestions and contributions.

\section{REFERENCES}

Adesina, G.O., Onaolapo, J.A., Ehinonido, J.O. and Odama, L.E. (2010). Phytochemical and Antimicrobial Studies of Ethyl Acetate Extract of Alchornea cordifolia Leaf Found in Abuja, Nig. Journal of Medicinal Plant Research, 4(8):649-658.

Akuodor, G.C., Mbah, C.C., Anyalewechi, N.A., Idris-Usman, M., Iwuanyawu, T.C. and Osunkwo,

U.A. (2011). Pharmacological Profile of Aqueous Extract of Bridelia ferruginea Stem Bark in the Relief of Pain and Fever. Journal of Medicinal Plant Research; 5 (22): 5366-5369.

Akuodor, M.E., Mbah, C.C., Essien, A.D., Akpan, J.L., Ezeokpo, B.C., Iwuanyanwu, T.C. and Osunkwo, U.A. (2012). Ulcer-protective and Antidiarrhoeal Effects of the Aqueous Stem Bark Extract of Bridelia ferruginea in Rodents. Pharmacol; 3:591-597.

Arsad, S.S., Esa, N.M., Hamzah, H. and Othman, F. (2013). Evaluation of Acute, Subacute and 
Subchronic Oral Toxicity of Rhaphidophora decursiva (Roxb.) Schott Extract in Male Sprague Dawley Rats. Journal of Medicinal Plant Research, 7 (41): 3030-3040.

Awodele, O., Amagon, K.I., Agbo, J. and Prasad, M.N.V. (2015). Toxicological Evaluation of the Aqueous Stem Bark Extract of Bridelia ferruginea (Euphorbiaceae) in Rodents. Interdisciplinary Toxicology, 8 (2): 89-98.

Bariweni, M.W., Yibala, O.I. and Ozolua, R.I. (2018). Toxicological Studies on the Aqueous Leaf Extract of Pavetta crassipes (K. Schum) in Rodents. Journal of Pharmacy $\mathcal{E}$ Pharmacognosy Research, 6 (1): 1-16.

Ellacott, K.L., Morton, G.J., Woods, S.C., Tso, P. and Schwartz, M.W. (2010). Assessment of Feeding Behavior in Laboratory Mice. Cell Metabolism, 12 (1): 10-17.

Hilaly, J.E., Isaili, Z.H. and Lyoussi, B. (2004). Acute and Chronic Toxicological Studies of Ajuva iva in Experimental Animals. Journal of Ethnopharmacology, 91: 43-50.

Kennedy, G.L., Ferenz, R.L. and Burgess, B.A. (1986). Estimation of Acute Oral Toxicity in Rats by Determination of Approximate Lethal Dose rather than the $\mathrm{LD}_{50}$. Journal of Applied Toxicology, 6 (3): 145-148.

Kharchoufa, L., Bouhrim, M., Bencheikh, N., El Assri, S., Amirou, A., et al. (2020). Acute and Subacute Toxicity Studies of the Aqueous Extract from Haloxylon scoparium Pomel (Hammada scoparia (Pomel)) by Oral Administration in Rodents. BioMed Research International, vol. 2020, Article ID 4020647, 11 pages.

Kolawole, O.M., Olayode, J.A., Oyewa, O.O., Adegboye, A.A. and Kolawole, C.F. (2009). Toxicological Renal Effects of Bridelia ferruginea-treated wastewater in Rats. African Journal of Microbiology Research, 3 (3): 82-87.

Larbie, C., Arthur, F.K.N., Woode, E. and Terlabi, E.O. (2011). Evaluation of Acute and Subchronic Toxicity of Annona muricata (Linn.) Aqueous Extract in Animals. European Journal of experimental Biology, 1 (4): 115-124.

Moshi, M.J. (2007). Brine Shrimp Toxicity Evaluation of Some Tanzanian plants used Traditionally for the Treatment of Fungal Infections. African Journal of Traditional Complementary Alternative Medicine, 4:219-225.

Njamen, D., Nkeh-Chungaga, B.N., Tsala, E., Fomum, Z.T., Mbanya, J.C. and Ngufor, G.F. (2012). Effect of Bridelia ferruginea (Euphorbiaceae) Leaf Extract on Sucrose-induced Glucose Intolerance in Rats. Trop. J Pharm Res; 11: 759- 65.

Osihembe, M., Abdulrahman, B.O. and Onoagbe, I.O. (2016). Acute Toxicity of Aqueous and Ethanolic Extracts of Strophanthus hispidus Stem Bark. IJBcRR, 9 (1): 1-5.

Saad, O., Azaizeh, H., Abu-Hijleh, G. and Said, O. (2006). Safety of Traditional Arab Herbal Medicine. Evidence-Based Complelementary Alternative Medicine, 3:433-9. 